\title{
Adaptation of Post-Industrial Areas as Hydrological Windows to Improve the City's Microclimate
}

\author{
Rafał Blazy *(D), Hanna Hrehorowicz-Gaber and Alicja Hrehorowicz-Nowak \\ Department of Spatial Planning, Urban and Rural Design, Faculty of Architecture, Cracow University of \\ Technology, 31-155 Cracow, Poland; hanna.hrehorowicz-gaber@pk.edu.pl (H.H.-G.); h.alicja@o2.pl (A.H.-N.) \\ * Correspondence: rblazy@pk.edu.pl; Tel.: +48-12-628-20-50
}

\begin{abstract}
Post-industrial areas in larger cities often cease to fulfill their role and their natural result is their transformation. They often constitute a large area directly adjacent to the city structure and are exposed to urbanization pressure, and on the other hand, they are often potential hydrological windows. The approach to the development strategy for such areas should take this potential into account. The article presents the example of Cracow (Poland) and post-industrial areas constituting the hydrological and bioretention potential in terms of the possibility of their development and the legal aspects of the development strategies of these areas.
\end{abstract}

Keywords: post-industrial areas; spatial planning; bioretention; urban microclimate

Citation: Blazy, R.;

Hrehorowicz-Gaber, H.;

Hrehorowicz-Nowak, A. Adaptation

of Post-Industrial Areas as

Hydrological Windows to Improve the City's Microclimate. Energies 2021, 14, 4488. https://doi.org/10.3390/ en14154488

Academic Editors: Christian Inard and Tristan Kershaw

Received: 31 May 2021

Accepted: 20 July 2021

Published: 24 July 2021

Publisher's Note: MDPI stays neutral with regard to jurisdictional claims in published maps and institutional affiliations.

\section{Introduction}

The world is becoming more and more urbanized, with larger, denser conglomerates of buildings. Compact cities are perceived as more energy-efficient and resource-efficient, but they have an influence on the intensification of microclimatic effects. Areas of thermally massive, impermeable surfaces, typical of dense urban centers, store heat, distorting the diurnal temperature cycle, increasing surface water runoff, increasing the risk of flooding, and reducing evapotranspiration that can cool the air and promote vertical heat transport away from the city. The methods of sustainable rainwater management include, first of all, bioretention systems, including ditches and moguls covered with vegetation, wetlands, but also green roofs and rain gardens [1]. Depending on the type and purpose, bioretention systems can basically fulfill all functions included in the so-called ecosystem service. The most important are regulatory functions related to the control of floods and inundations, influencing the microclimate and ensuring adequate water quality [2]. The last of the above-mentioned tasks requires the use of solutions with the appropriate potential to remove pollutants contained in rainwater runoff and wastewater from rainwater sewage. The regulating function, including the purifying function of the sustainable rainwater management systems, can be strengthened and expanded by introducing solutions that intensify the natural treatment processes. These processes should be supported by the presence of aquatic and water-loving plants. The development of appropriate plant species supports the processes of biological decomposition of organic matter and leads to periodic bioaccumulation of nitrogen and phosphorus in plant tissues. Actions to improve the condition of the environment can be carried out, but always more effective and comprehensive are actions supported by the city's development strategy and anchored in spatial planning. The hydrological windows created during functional changes in the city tissue offer the potential to improve the management of surface runoff. Cracow is at the stage of structural changes and the liquidation of industrial functions in the city. These potential hydrological windows created in this area could significantly improve the city's environment, provided that they are kept as open, green areas. Measurements show that in the face of a changing climate, progressive urbanization poses a significant threat to human health. This special issue will bring together the latest research on how 
we can design buildings and urban areas to reduce the risk of climate change and mitigate the heat island effect and improve environmental resource efficiency. Thanks to this holistic approach, we can create truly resilient urban areas and minimize the impact of the intensifying microclimatic effects responsible for the urban heat island effect.

\section{The Problem of Bioretention in Metropolitan Areas}

Bioretention is located in the lowest parts of the terrain topography and often uses recessed plant sites. It can take very different forms, ranging from a point pot with hydrophilic vegetation to entire rain gardens. Vegetation makes it possible to include bioretention in an urban design. The plant multilayer structure is especially valuable here, as it enables effective evapotranspiration. It is also an important element enabling framing of views and creating visually attractive urban interiors and perspective closures. Sustainable Drainage Systems (SuDS) is multi-functional and combines the issues of rainwater management and the protection and maintenance of biodiversity in the city. A special position of bioretention in terms of the goals of utility in rainwater management is presented by Echols and Pennypacker [3], from which research shows that it is bioretention that provides the greatest amenities in terms of education, recreation, safety, and even PR and aesthetics. At the same time, they point out that infiltration is a challenge when assessing bioretention and its aesthetics, since infiltrated water is visible only through the presence of vegetation, not directly. Criteria for assessing the appearance and aesthetics of projects related to rainwater management were developed by Backhaus and Fryd [4], pointing to the essence of choices made in the design process.

The concept of hydrological windows used in the literature [5] very well reflects the metaphorical "larger areas" in the urban tissue, referring them to all areas enabling the retention of rainwater and meltwater-in the form of surface and underground retention. For almost 10 years, we have had a problem in Poland consisting in a low level of water in surface watercourses. We are affected not only by agricultural drought, but also by a hydrological drought manifested by a lack of water in rivers, as well as a hydrogeological drought consisting in a shortage of groundwater. In Poland, there is an average of about $1600 \mathrm{~m}^{3}$ /year of water resources per capita, during droughts it is only about $1000 \mathrm{~m}^{3}$ /year, which is several times less than the average of water resources for an average European (4500 $\mathrm{m}^{3}$ /year) [6]. In terms of climate change, the priority is rainwater retention, i.e., collecting it at the point of precipitation. We can save the situation by applying system solutions from relatively simple solutions dedicated to individual residents (rainwater capture, not mowing lawns, shower instead of a bathtub), to extensive green and blue infrastructure, which consists of commonly known green elements (parks, flower meadows, squares) and surface waters and assisted underground tanks for rainwater. Rainwater retention is favored by retention roofs, wet and dry rain gardens, absorbent ditches, rain gardens in containers on garage roofs or under gutters, tall greenery [7]. Not only do trees trap water, they also help lower temperatures in hot weather. The easiest way to keep water in the city is to keep it green. High and compact vegetation promotes water retention in the ground and reduces evaporation in hot weather. Traditional lawns are a poor method of retaining rainwater: they do not absorb a lot of rainfall, and at the same time they strongly evaporate and give a large amount of water to the air. Moreover, they poorly fit into the biodiversity system, not providing a basis for its enrichment. Natural meadow and grass greenery lowers both environmental costs and limits the water consumption for irrigation, which is often a significant consumption of drinking water in lawns. Apart from drought, heavy rainfall is the second most important problem of cities (Figure 1). Take-offs are flooding of basements, infrastructure, parking lots, city center. In built-up areas, over $90 \%$ of rainwater flows through the sewage system to rivers. Sealing urban catchments causes cities to lose their natural retention methods, and concrete prevents water from freely seeping into the ground, which increases the sensitivity to drought, but during downpours, asphalt streets turn into rushing rivers. 


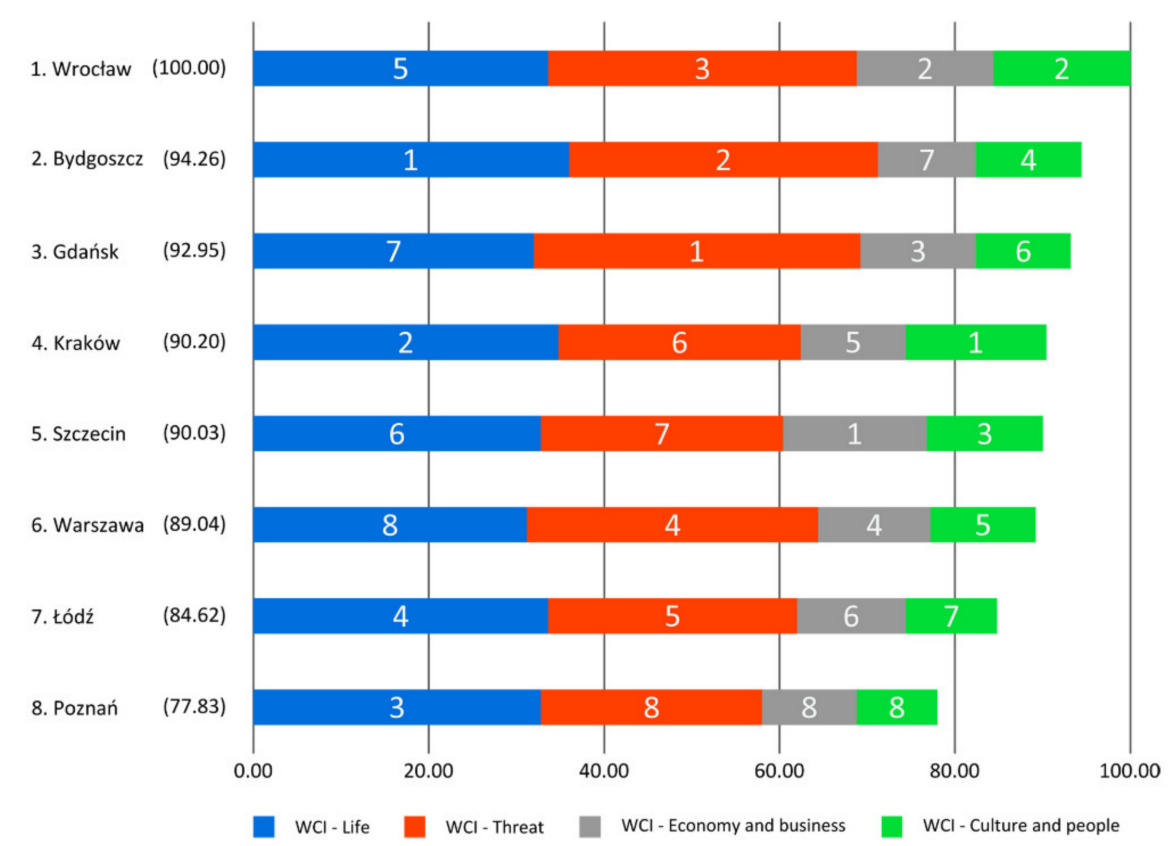

Figure 1. Ranking of the effectiveness of the use of water resources in Polish cities. Source: oees.pl/ water-city-index-2020/ (accessed on 23 May 2021).

The Water City Index 2020 ranking carried out in Poland has been prepared separately for metropolises (8), the category of cities with poviat rights (58) and for cities that are not cities with poviat rights, with at least 20,000. inhabitants (152). The index was prepared within four categories and 15 sub-categories of evaluation. Cracow took 4th place among metropolitan cities. The four main categories in which the efficiency of urban water management was assessed are:

- way of using water resources

- $\quad$ ability to deal with water crises

- use of water in the context of the economic development of cities

- and improving the quality of provided public services in the water sector.

Cracow is a city dynamically developing its building structure with a growing tissue. The areas released from non-residential functions (agricultural, industrial, post-military, post-military) turn into residential and service functions with high intensity of construction and low parameters of biologically active surface. An equally important aspect influencing the final changes in the functions of areas in the city is the fact that the benefits of creating hydrological windows are not taken into account in planning studies. An important element of each spatial development plan are the arrangements for the management of rainwater. It is regulated in local spatial development plans and results from regulation [8], paragraph 28 (1), which refers only to partial water management, stating that: "A building plot on which buildings are located should be equipped with a sewage system enabling the discharge of rainwater to the rainwater or combined sewage system", and resulting in the loss of water resources. This loss has an environmental and an economic dimension. And with time also infrastructure, because the thickening of the tissue will cause an increase in the amount of rainwater transferred to the sewage system.

\section{Materials and Methods}

The research shows the analysis and characteristics of potential hydrological windows in Cracow against the background of the environmental characteristics of the city and the expected profits from the use of areas of the decommissioned industry. The authors, additionally, based on the optimal species of vegetation, indicated possible methods of using individual species. 


\subsection{Environmental and Climatic Conditions Related to the Location of Cracow}

Cracow is known in the world primarily for its centuries-old heritage, inscribed in the fabric of the city. However, it was also an industrial center, the beginnings of which date back to the 19th century, the industrial revolution and the location of enterprises such as: Zieleniewski, Piasecki and Peterseim in Cracow. The post-war period made it a very important industrial center of Poland and the center of the Cracow Industrial District, which included smaller towns located today in the metropolitan area-primarily: Bochnia, Myślenice, Skawina, Wieliczka, Trzebinia, Chrzanów and Olkusz. Cracow specialized mainly in the metallurgical industry and related functions, but not only. The flagship investment of that time was Lenin's ironworks (Huta im. Lenin) launched on 22 July 1954.

The city is located on the lower border of the moderately warm climate of Karpat, as a type of basin climate. It is characterized by a wide variety of weather conditions, resulting from the influx of various air masses to this area, mainly polar-sea, causing thaws and precipitation in winter, and cooling, precipitation and storms in summer, and to a lesser extent: warm tropical-sea throughout the year. or continental, as well as always cool and dry Arctic air. The city's climate, compared to non-urban areas, is distinguished by, inter alia, higher air temperature, lower values of relative humidity and a greater number of dry days, fewer days with fog, more days with a storm, weaker solar radiation intensity, lower wind speeds, shorter dependence-snow cover or greater air pollution [9].

The most characteristic feature of the city's climate is the presence of higher air temperature values in the center of the agglomeration than in its outskirts. This phenomenon is known as the urban heat island. The influence of the city on the air temperature is more pronounced in the case of its minimum values, rather than the maximum ones. The average annual air temperature for Cracow is $8.8^{\circ} \mathrm{C}$ (Table 1). In Cracow, annual precipitation totals most often reach values in the range of $650-730 \mathrm{~mm}$, and the average annual rainfall is $688 \mathrm{~mm}$ [10]. Precipitation of this type, genetically related to the flow of air from the northern quadrant, is the most common cause of flooding in the upper Vistula basin. All this is related to the location of cities in the floodplains of the Vistula River (Figure 2). Many of the current limitations in the city's development and environmental conditions, such as areas of stagnant fogs or easily formed smog, result from the original location of the city in the area of the Vistula overflow.

Table 1. Distribution of average temperatures and precipitation.

\begin{tabular}{ccc}
\hline Months & Temperature $\left({ }^{\circ} \mathbf{C}\right)$ & Storm Water $(\mathbf{m m})$ \\
\hline I & -2.2 & 40 \\
II & -0.7 & 31 \\
III & 3.7 & 41 \\
IV & 9.3 & 44 \\
V & 13.9 & 82 \\
VI & 16.9 & 87 \\
VII & 18.9 & 98 \\
VIII & 18.6 & 80 \\
IX & 14.3 & 61 \\
X & 9.8 & 41 \\
XI & 4.3 & 45 \\
XII & -0.6 & 38 \\
Year avg. & 8.8 & 88 \\
\hline
\end{tabular}




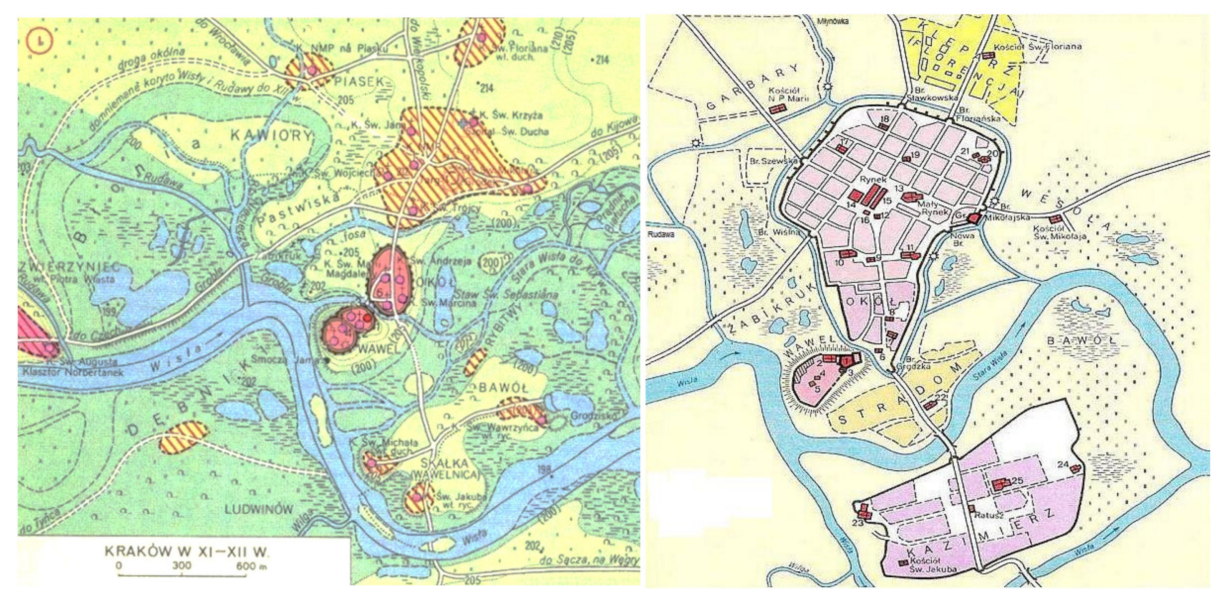

Figure 2. Pre-colection settlement layout of Cracow from the 11th/12th century (on the left) and the urban location layout from the 13th/14th century (on the right).

On the one hand, swamps and wetlands are a factor limiting the city's development, and at the same time they are very important areas for natural water retention. They are particularly valuable components of the natural system due to their role in shaping the microclimate as well as aesthetic and recreational values. They are the mainstay of many important and valuable flora and fauna communities. Over the years, along with the development of the city, they underwent a transformation, often leading to a complete disappearance. Despite this, there are still many wetlands in Cracow, which constitute valuable natural and landscape enclaves. The amount of rainfall from June to August (the maximum rainfall occurs in July) is almost three times higher than in the winter season, which proves a large degree of pluvial continentalism in Cracow.

Precipitation in Cracow occurs on average 173 days a year. In the center of Cracow, on average, there are about 30 days with a storm every year [11]. These values in combination with the increasing density of the urban tissue cause a conflict between the natural conditions of the environment and human activity, which is in conflict with the balancing of the city's development. Miejskie Przedsiębiorstwo Wodociagów i Kanalizacji S.A. (MPWiK S.A., Warshaw, Poland) states that the sewage system of Cracow is solved in a combined system in the central parts of the city and a distribution system on its outskirts, in the vicinity of rivers. The peripheral areas of Cracow are intended for sewerage in local systems. The city still has deficiencies in the technical infrastructure, mainly in the collection and treatment of wastewater and rainwater, and in water supply. These deficiencies occur mainly on the outskirts, in the so-called "peripheral areas" of Cracow. The growing problem of rainwater management remains to be solved in areas where there is intensive investment.

There are potentially many reasons for this state of affairs (infrastructural, financial and awareness shortages), but it is worth focusing on the possibilities of its improvement.

\subsection{Green Areas in Post-Industrial Areas-Changes in Industrial Structures and Green Areas in the Last 50 Years}

In the Polish reality, changes in infrastructure to improve municipal water management take place slowly. This is combined with changes in land use in the changing image of the city. The importance of integrated urban landscape planning for the management of water resources seems to be extremely important. In particular, it is necessary to emphasize the importance of biologically active hydrological windows with bioretention functions that may arise in post-industrial areas, replacing the operation of technical devices with their operation. Due to the history of these places, it would be important to preserve the memory of their former function and to leave some post-industrial relics in an ecologically active landscape [12]. The areas of hydrological windows can be included in a network of green-blue infrastructure [13], because in this area there will be bioreactive basins, artificial 
wetlands, mineral and plant filters-used in biologically active water reservoirs. The changes in the city's structure are incremental and are related to development pressure and insufficient legal protection. In recent years, the investment pressure in Cracow has resulted in a fourfold increase in employment in service and business areas. It grows every year, causing changes in the city space. In Cracow, there was a definitive collapse of industry and with it the liquidation of jobs. Today, the expectations of the post-industrial society are different. We want to live in an ever cleaner environment. We stop producing there, generating and processing information. Housing and office estates are built on the site of former factories, warehouses and enterprises. Industrial facilities are disappearing from the city structure and replaced by office buildings of international corporations. "Fabryka Zieleniewskiego" (Zakłady Budowy Maszyn i Aparatury im. L. Zieleniewski S.A. (Table 2), Cracow, Poland) has given way to blocks of flats, and the "Polmos" alcoholic beverages factory has also disappeared. The same happened with the Artigraph factory at ul. Prąnicka, as well as the service area, the Peterseima factory at ul. Zółkiewski.

Table 2. Comparision of the change in the function of the industrial area in Cracow as a potential hydrological window on the example of one of the factories in Cracow. Restructuring completed in 2021.

\begin{tabular}{ccc}
\hline \multicolumn{3}{c}{ Machines and Apparatus Construction Plant im. L. Zieleniewskiego SA w Cracowie } \\
\hline Land Cover & Historical Condition-1970 & The Current State-2021 \\
\hline $\begin{array}{c}\text { Objects and surfaces } \\
\text { of hardening }\end{array}$ & 10.5 ha industrial facilities & $\begin{array}{c}10.5 \text { ha of housing, service } \\
\text { and parking facilities } \\
\text { Biologically active areas }\end{array}$ \\
\hline
\end{tabular}

When analyzing the areas of decommissioned industry over the last half-century, it should be noted that they are dispersed against the city's buildings (Figure 3). If only the potential of these areas were used as such that enable the retention of rainwater and snowmelt, Cracow would have a much better microclimate, a more coherent network of green and blue infrastructure and lower loads of water discharge into the sewage system. Unfortunately, this did not happen and only 3 larger areas gained biologically active functions. The first is the Zakrzówek limestone quarry. The closed excavation (1992) was reclaimed by flooding it with water. Currently, ecologists are fighting for the species protection of the blue tit and smooth snake, which makes it easier to keep it and its surroundings as a green area. The Regional Directorate for Environmental Protection is working on including this area and its buffer zone [14]. A small quarry-meme in nature protection (inanimate nature reserve) is also a marl mining quarry called Bonarka (until 1961).

Another area, also post-mining, is the area of the limestone quarry called Lebanon (named after the owner). The quarry area was excluded from production in 1986. Others, of which there were 7 more in this location, were closed, as was Lebanon by 1986 [15]. The Liban quarry is also subject to vegetation succession, and its bloody history (it was a labor camp established by the Nazis during the occupation of Cracow in 1942) prevented any attempts to urbanize it.

Most of the brownfield sites failed to withstand the investment pressure [16,17]. Most of them have been densely built-up, preventing free water filtration. Industrial areas that still perform technical functions include the municipal heating plant MPEC SA, located in the area between Cracow and the Nowa Huta district, close to the river. It is an industrial and communal function, the purpose of which is not threatened by any changes so far, and the area is used extensively, giving place to the green structure. 


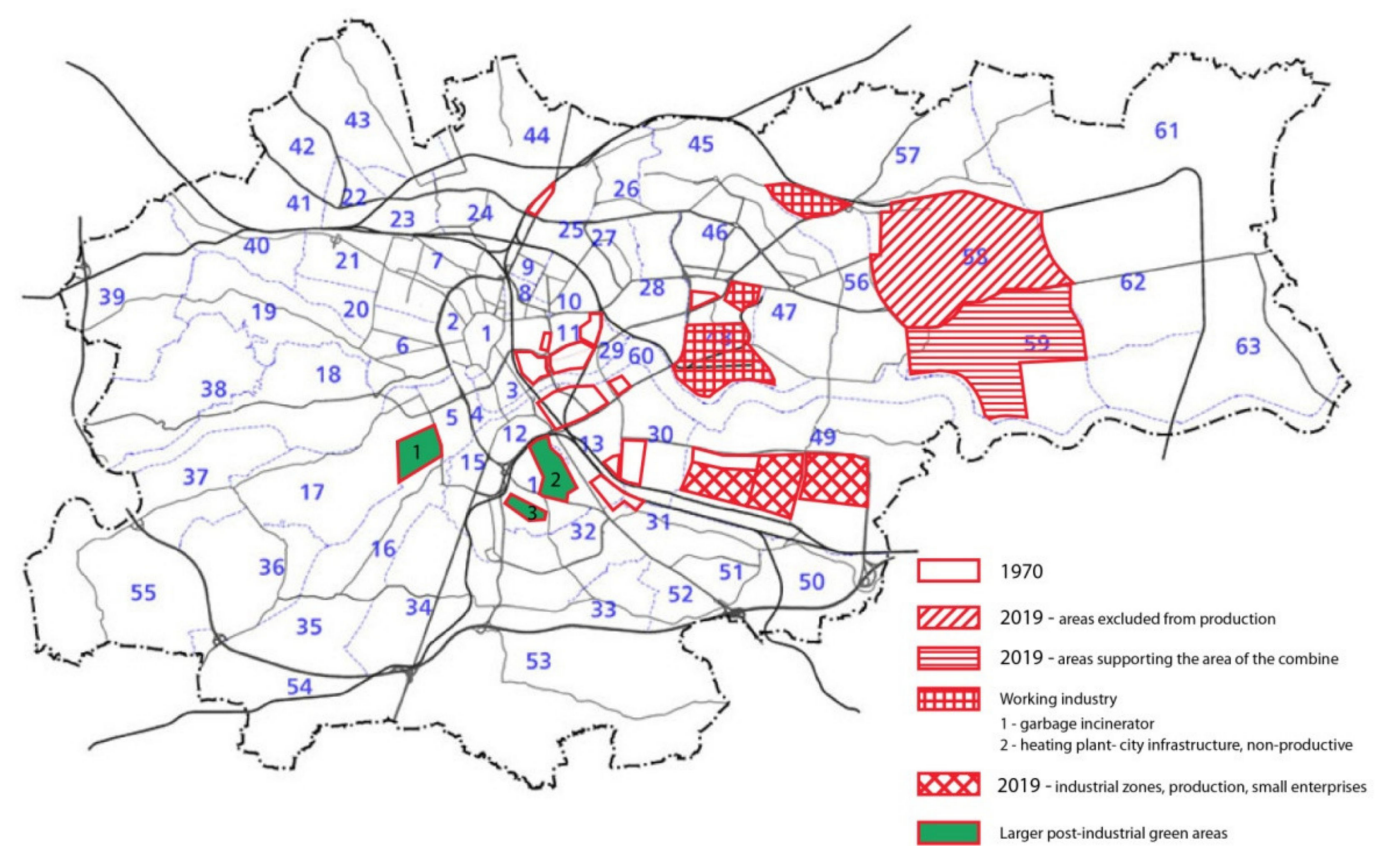

Figure 3. Spatial and functional changes in the field of industry functions in the last 50 years in Cracow.

The production area (or actually in 2021 already post-production) is the former metallurgical plant (originally the Lenin Steelworks, until 1990, and then T. Sedzimir until 2004 and now Acellormittal) for which a whole residential district was built. The area of the smelter was combined with the areas to the south of it, which served as auxiliary waste dumps, treatment plants, settling tanks, etc. The area is adjacent to the immediate vicinity of the Vistula River and its vegetation is degraded as a result of industrial use.

These areas and other larger post-industrial areas are located in the river valley and in the oxbow lake of the Vistula. The direction of their transformation and hydrological protection are all the more important. Most of these areas have native vegetation of a bioretical nature characteristic of wetlands.

Plant species occurring in the area of the Vistula valley in its upper course-for rainwater management under bioretention, based on [18] (Table 3).

Table 3. Plant species occurring in the area of the Vistula valley in its upper course.

\begin{tabular}{ccc}
\hline Vegetation & & Occurrence \\
\cline { 2 - 4 } & Frequent & Increasingly Rarer or Unitary \\
\hline Alnus incana (L.) Moench & $\checkmark$ & \\
Cornus sanguinea & $\checkmark$ & \\
Populus alba L. & $\checkmark$ & \\
Salix alba L. & $\checkmark$ & \\
Salix aurita L. & $\checkmark$ & \\
Salix purpurea L. & $\checkmark$ & \\
Salix viminalis L. & $\checkmark$ & \\
Salix fragilis L. & $\checkmark$ & \\
Betula pendula & $\checkmark$ & \\
Lysimachia vulgaris L. & $\checkmark$ & \\
Lythrum salicaria & & \\
Myosotis palustris & $\checkmark$ & \\
Petasites hybridus & $\checkmark$ & \\
Stellaria nemorum & $\checkmark$ & \\
Symphytum officinale L. & $\checkmark$ & \\
Aegopodium podagraria & & \\
Caltha palustris L. & & \\
\hline
\end{tabular}


The substrate is also important in the entire bioretention system [19]. It is in the Vistula valley at the beginning of the Carpathian Foredeep that it seems naturally adapted. The use of a bioretention system requires $\mathrm{min}$. about $5 \%$ of the ground area of the area from which rainwater is collected, therefore the best candidates for their application are hydroelectric windows with free peripheral areas, parking lots and large buildings. The areas where the existing solutions for draining rainwater require modernization are particularly suitable for the introduction of a bioretention system. In the areas subject to bioretention, an important factor enabling water retention are various types of land depressions, basins, water reservoirs rich in water-loving vegetation. Management of surface runoff is carried out in the areas of bioretention in 4 zones (Table 4 ).

Table 4. Bioretention zones with their vegetation.

\begin{tabular}{|c|c|c|c|}
\hline Zone 1 & Zone 2 & Zone 3 & Zone 4 \\
\hline $\begin{array}{l}\text { the area of tanks } \\
\text { under water }\end{array}$ & $\begin{array}{l}\text { periodically the area } \\
\text { below the water table }\end{array}$ & $\begin{array}{l}\text { periodically the area } \\
\text { under the water table }\end{array}$ & $\begin{array}{l}\text { the area constantly } \\
\text { above the water table }\end{array}$ \\
\hline Water plants & Water-loving plants & $\begin{array}{l}\text { Vegetation withstands } \\
\text { periodic flooding }\end{array}$ & $\begin{array}{c}\text { The vegetation of the } \\
\text { riparian areas }\end{array}$ \\
\hline
\end{tabular}

Each of these zones has a bioretention function and also purifies the aquatic environment. Of course, it is impossible to list all potential plants in all zones, so the table above presents the most popular for southern Poland and the river valleys located in it (Table 5).

Table 5. Plant species occurring in the area of the Vistula valley in its upper course based on [20].

\begin{tabular}{ccc}
\hline \multirow{2}{*}{$\begin{array}{c}\text { Zone 2 } \\
\text { Examples of Plant Species }\end{array}$} & \multicolumn{2}{c}{ Bioaccumulation kg/year } \\
\cline { 2 - 3 } & Nitrogen [N] & Phosphorus [F] \\
\hline Typha latifolia & $500-2630$ & $75-403$ \\
Juncus L. & 800 & 110 \\
Scirpus & 125 & 18 \\
Phragmites australis & 225 & 35 \\
\hline
\end{tabular}

The development of appropriate plant species supports the processes of biological decomposition of organic matter and leads to periodic bioaccumulation of nitrogen and phosphorus in plant tissues. As shown by studies in plant tissues, 5-10\% of the load supplied to the nitrogen system can be periodically retained. The amount of bioaccumulated nitrogen depends both on the type of plants and their growth phase. You can see the multi-layered benefits of using bioretention here.

\section{Results}

Cracow is characterized by extraordinary development dynamics, including building a gigantic new spatial structure of the city in the form of apartments, trade and service offices. In a relatively short period of dynamic economic development, the occupation of areas easily accessible for development, especially those that were not covered by the local plans, caused many inconveniences for the permanent residents of the city. Also, the historic buildings of the city are increasingly becoming a bedroom for visitors. There is an urgent need to create places of natural value for the inhabitants of the city. Bearing in mind the image presented above, a strategic decision should be made as soon as possible regarding the directions of development of the city of Cracow. The point is not to lose its strengths, and at the same time to provide its inhabitants with decent living conditions. The creation of high standards in this respect becomes a priority. 


\subsection{Cracow-Directions of Transformations of the Urban Tissue}

The original urban fabric - as in the case of Cracow, the Old Town, built in the Middle Ages-grew over time with successive quarters of buildings, which formed the downtown zone, then expanded its territory, starting with Nowa Huta, with enclaves of modernist buildings in the second half of the 20th century, and in the last decades achieve a "hybrid" form, dotted with a structure different in terms of the nature and type of development, often resulting from chance, without any reference to the historical tissue of the city center [21]. Among the areas undergoing constant transformation, 3 are worthy of in-depth analysis (Table 6). These areas are post-production areas marked with the letters A; B; C in (Figure 4).

Table 6. Comparison of areas due to the current function and the function proposed in the provisions of local development plan and Study of the conditions and directions of spatial development.

\begin{tabular}{cccccc}
\hline Area & MPZP ${ }^{1}$ & SUIKZP ${ }^{2}$ & Existing Feature & Proposed Feature & $\begin{array}{c}\text { Biologically Active } \\
\text { Surface-Bioretention } \\
\text { in the Proposal }\end{array}$ \\
\hline $\begin{array}{c}\text { A- “Nowa Huta } \\
\text { Przyszłości” }\end{array}$ & yes & $\begin{array}{c}\text { in the process } \\
\text { of changing }\end{array}$ & $\begin{array}{c}\text { Industrial open areas } \\
\text { with industry service } \\
\text { equipment }\end{array}$ & $\begin{array}{c}\text { Service and residential } \\
\text { areas with greenery }\end{array}$ & yes \\
$\begin{array}{c}\text { B-“Rybitwy } \\
\text { Nowe Miasto" }\end{array}$ & concept & $\begin{array}{c}\text { in the process } \\
\text { of changing }\end{array}$ & $\begin{array}{c}\text { Industrial areas, } \\
\text { residential areas, } \\
\text { service areas }\end{array}$ & $\begin{array}{c}\text { Service and residential } \\
\text { areas with greenery }\end{array}$ & yes \\
\hline $\begin{array}{c}\text { C-“Kombinat } \\
\text { Metalurgiczny" }\end{array}$ & no & $\begin{array}{c}\text { in the process } \\
\text { of changing }\end{array}$ & $\begin{array}{c}\text { Industrial and } \\
\text { post-industrial area }\end{array}$ & No direction of change & no \\
\hline
\end{tabular}

${ }^{1}$ Local spatial development plan.; ${ }^{2}$ Study of the conditions and directions of spatial development.

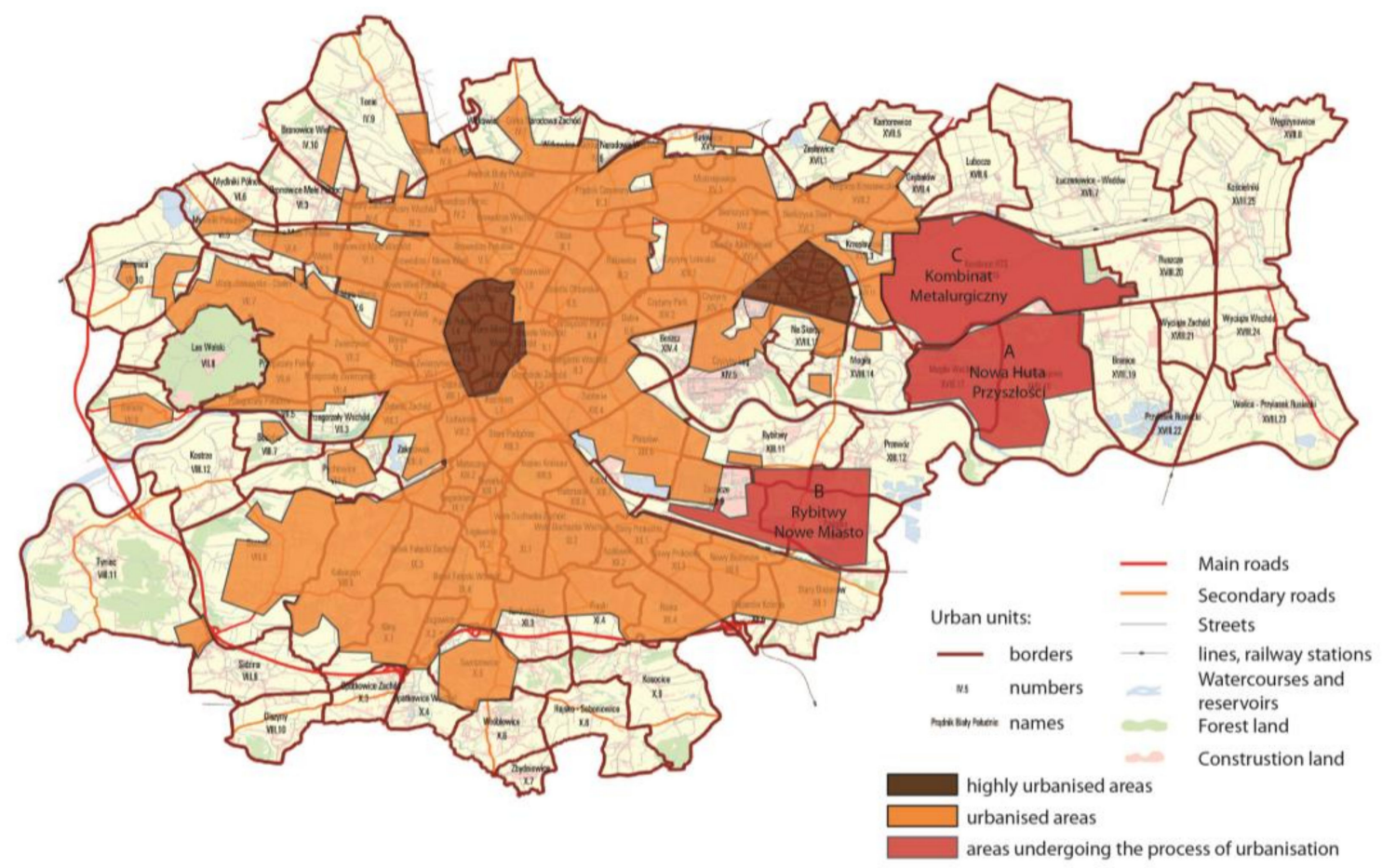

Figure 4. Scheme of highly urbanized areas and the direction of their development.

These are the last areas that can become a rainwater management potential. At the same time, they can retain their post-industrial character, pointing to the cultural heritage of this area and the rich multicultural history of the industry in Cracow. It is possible to link post-industrial structures with a simultaneous ecological function, especially biofiltration. 
The following 2 graphics (Figures 5 and 6) show the specificity of spatial changes in area B, which is a strategic area of key importance for the city's structure. The area performs service, trade and industrial functions important for the region (including the exchange of agricultural products). An urbanized structure with an area of 677.5 ha will be created in this area, it will be another district with a compact downtown character.

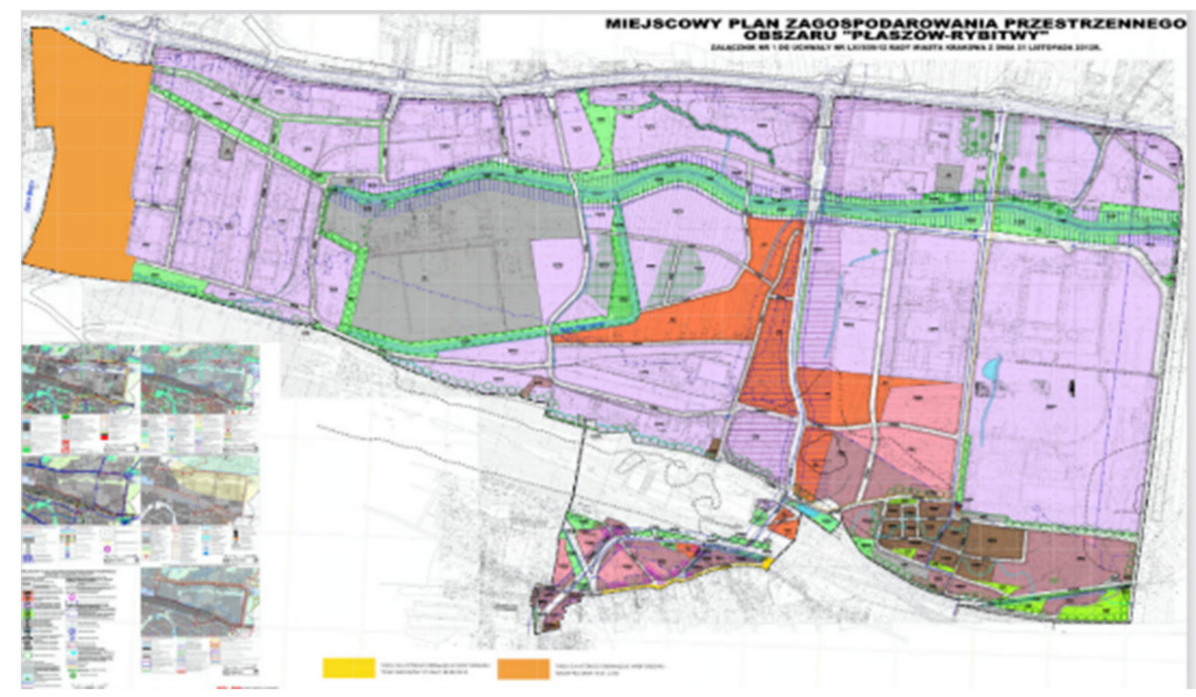

Figure 5. Changes in the approach to industrial and post-industrial areas in the B-Cracow Ry-bitwy area. MPZP—Status for 2013 [22].

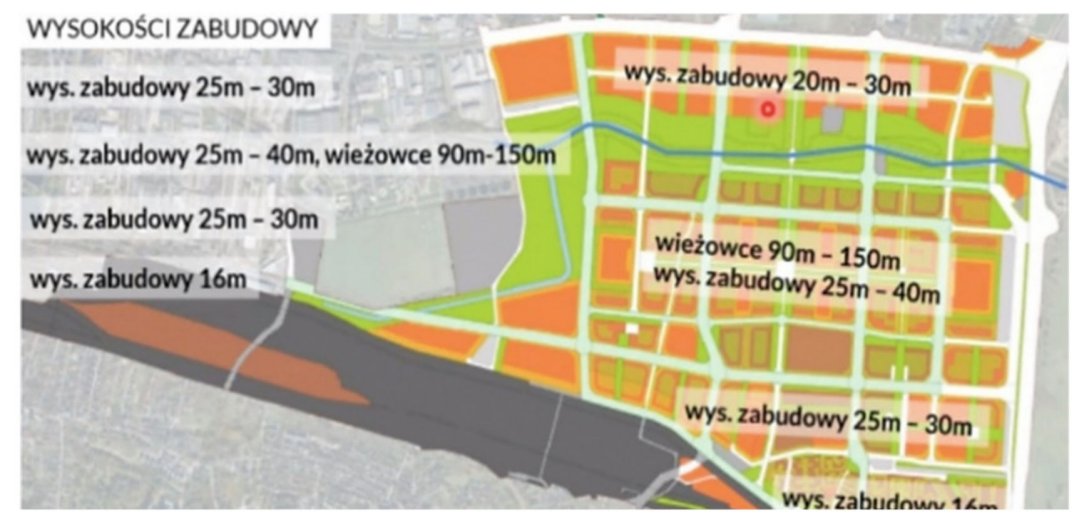

Figure 6. Changes in the approach to industrial and post-industrial areas in the B-Cracow Ry-bitwy area. A new development concept-As of 2021 [23].

\subsection{The Potential and Adaptation Possibilities of the Areas of the Metallurgical Plant}

The last area that can still take over environmental and natural functions and where there is not much investment pressure yet is the area of the metallurgical complex itself (Figure 7), still belonging to Acelormittal, however, after closing production and demolishing the last of the three blast furnaces 22/11/2019 on 23 April 2021, it is only a matter of time before Acelormittal sells its land. The city has already partially taken it over, and the Arcelormittal concern has disposed of a large part of the factory area along the eastern and western borders (Figure 8). In total, approx. 300 ha of land will be returned to the property of the state treasury. Until now, the global company had the entire area in the so-called perpetual lease. In exchange for the handing over of some unnecessary plots of land, about 500 ha of the area of the combined plant have now become the property of the concern. 


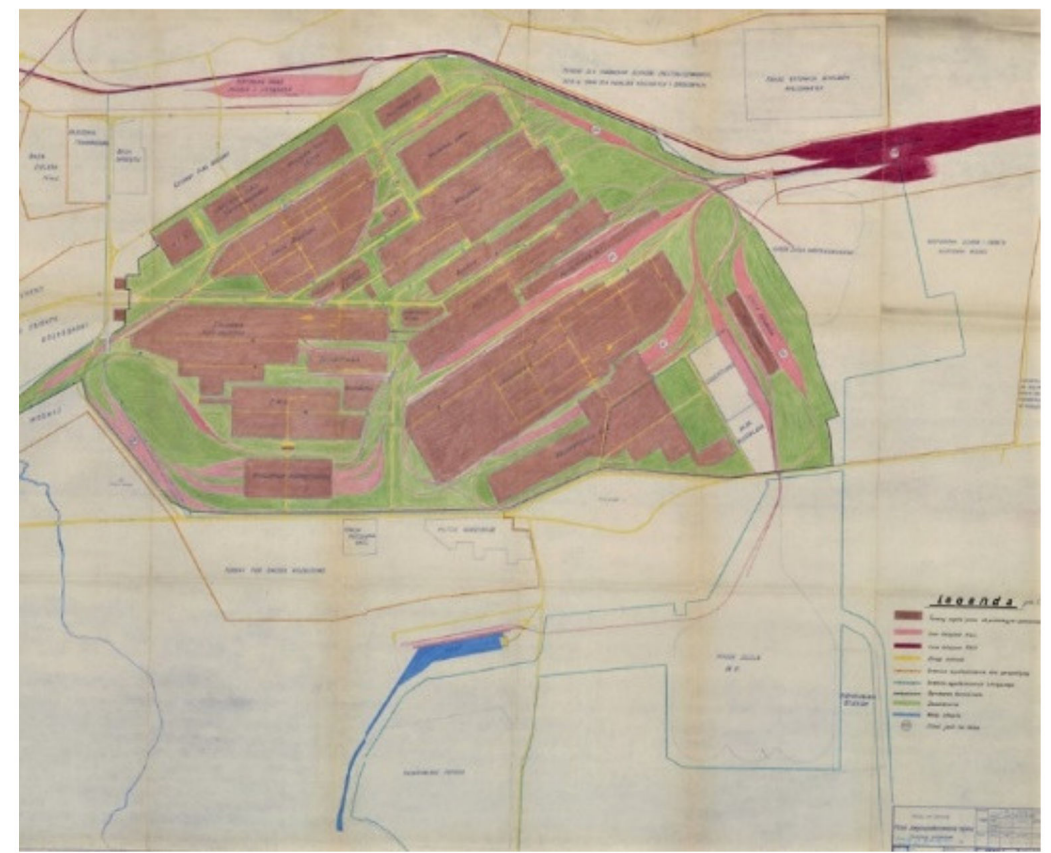

Figure 7. The functional and spatial concept of the metallurgical combine Huta im. Lenin-As of 1949.

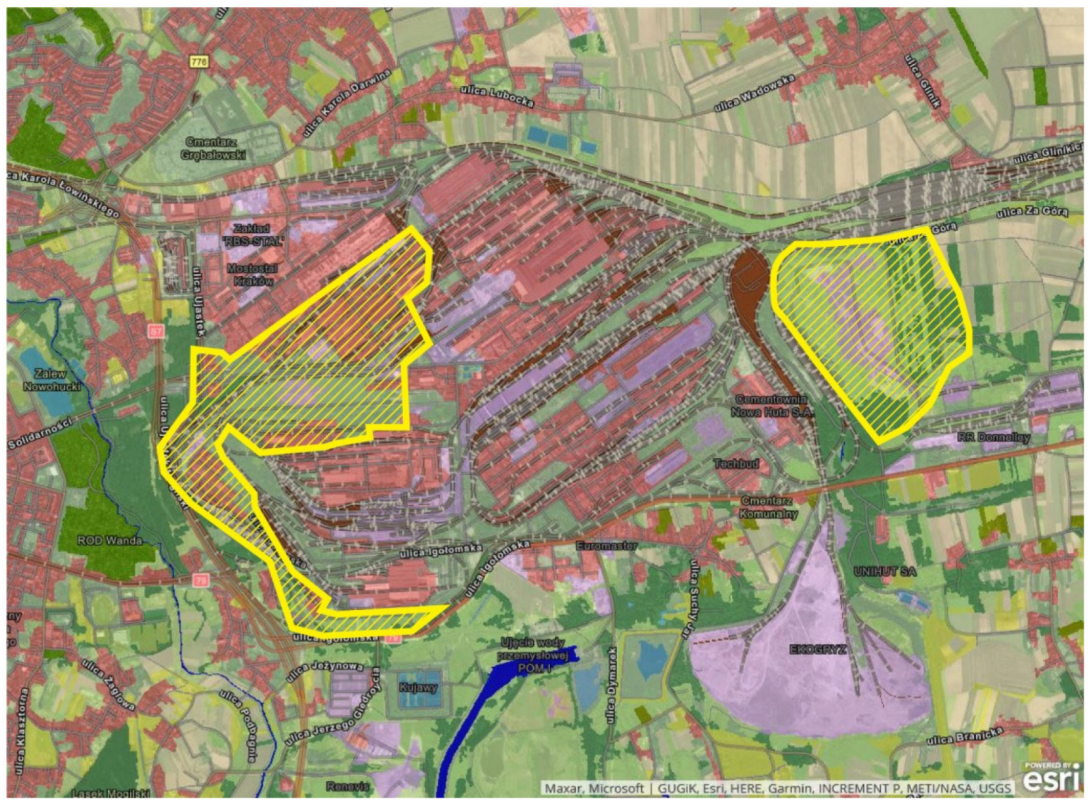

Figure 8. Areas taken over by the city and designated for urban functions and structures (marked in yellow on the background-Monit-air Atlas of Cracow [24]).

Cracow participates in the Lifeurbangreen project (on the Lifeurbangreen.eu platform and was selected as the reference city (together with Rimini in Italy and Taipei in Taiwan) The LIFE URBANGREEN project investigates how much $\mathrm{CO}_{2}$ is permanently absorbed and how much $\mathrm{CO}_{2}$ is stored in its biomass by trees. These data are calculated for the most common tree species and then applied to assimilated species that have very similar characteristics. This highlights the role of city trees as climate defenders. -mulation of environmental clean-up and pro-climatic activities The data published on the project website show that each tree of the analyzed species in Rimini and Cracow constantly stores an average of $30 \mathrm{~kg}$ of climate harmful $\mathrm{CO}_{2}$ annually. At the end of the day or the growing season, $\mathrm{CO}_{2}$ is released back into Environment in the form of organic matter (in the fall 
of leaves) or as a gas in the form of $\mathrm{CO}_{2}$ in the night. Among the studied tree species, the greatest amount of $\mathrm{CO}_{2}$ is accumulated and absorbed by (Populus nigra) and European oak (Quercus robur). Lips (Tilia) and plane trees (Platanus) are extremely effective in $\mathrm{CO}_{2}$ assimilation, provided that the hydrological conditions allow them, as they require more water. The area of the combine is planted mainly with poplars (Figure 9) (eagerly planted in Cracow and Nowa Huta in the second half of the 20th century. Particularly eager to emphasize the importance of the main routes, they were planted with soaring Italian poplars. The river Dłubnia to the Vistula is the greenery accompanying the river valleys. Some of the trees grew as ruderal green in areas changed by the construction of the steelworks. Poplars, willows, acacia and birches are among them. Maples, oaks and conifers are among the species.
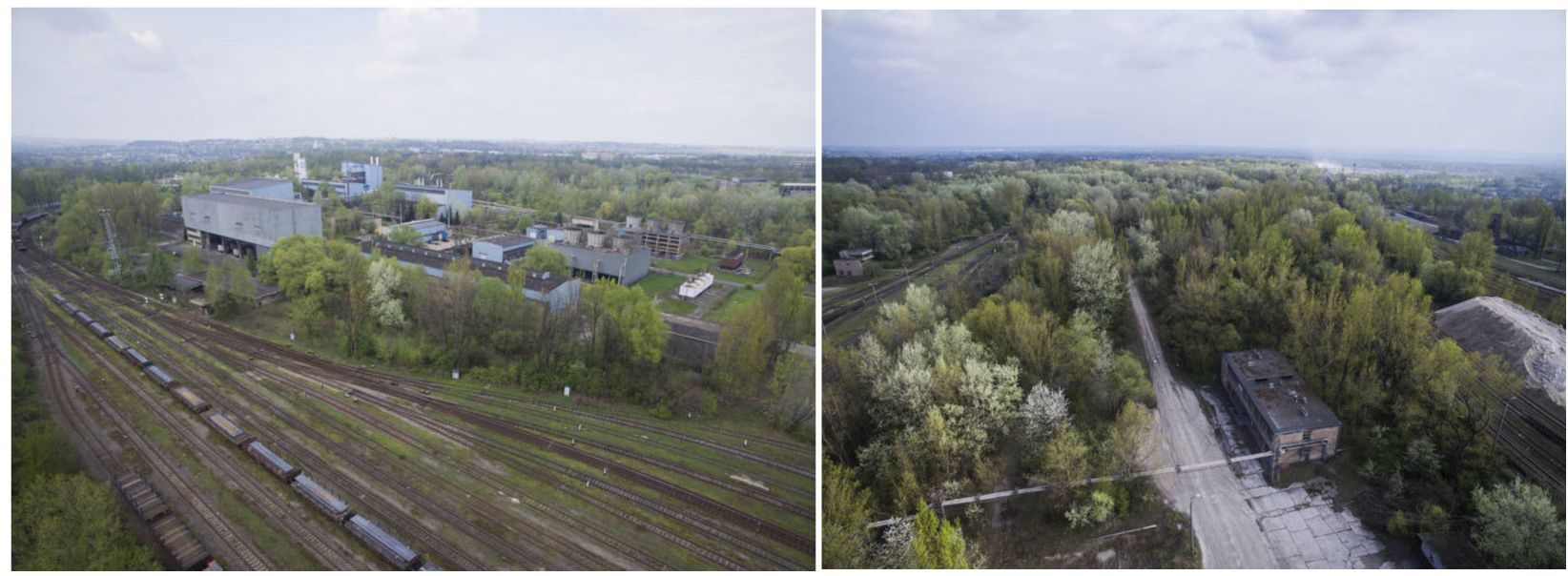

Figure 9. Pictures from the drone to the steelworks area (Kombinat). Author: Joanna Urbaniec, 2018.

In the area of the conglomerate, the area is used in the usual way, only some elements have been excluded from production (e.g., coking plant, steel plant, blast furnaces and operating equipment). However, the areas after demolition or unused have not assumed a new function and are still ongoing as areas for revitalization and greening (Table 7). These include: railroad tracks, fuel, scrap, iron ore and agglomeration storage sites).

Table 7. Approximate share of land cover in the area of Acelormittal (Combine) plants.

\begin{tabular}{cc}
\hline Type of Land Cover & Area (ha) \\
\hline Total area & 790.00 \\
Tall trees and bushes & 170.62 \\
Low green, unadorned & 217.27 \\
Arranged green area & 16.9 \\
Industrial facilities and devices & 104.18 \\
Office buildings & 10.03 \\
Technical infrastructure & $205.4(26 \%)$ \\
Paved areas—concaves of unknown function & 51.60 \\
Other facilities (silos, tanks, warehouses) & 14.00 \\
\hline
\end{tabular}


An analysis of the literature on the subject makes it possible to assess the significant benefits that result from the creation of a hydrological window, also indicating that such benefits are possible to determine and forecast. In particular, the improvement of the interdependence of rainfall and runoff, evaporation, infiltration and reclamation of water, as can be seen in the research conducted by Kelleher, C.; Golden, H.E. [25]; Elliott, R.M.; Adkins, E.R. [26] and Nguyen, T.T.; Ngo, H.H.; presenting the concept of Sponge City and its advantages [27]. Determining the exact parameters of the change of a specific area (Combine) in the event of the creation of a hydrological window would require further research in the field of hydrology, but even without them, the validity of the hydrological windows can be easily seen.

\section{Discussion-Studies on Industrial Transformation in Urban Areas-European Examples of Good Practice}

4.1. The Potential and Adaptation Possibilities of the Areas of the Metallurgical Plant

\subsubsection{IBA Emscher Park}

Cities in Germany account for over $75 \%$ of the total population of Germany. As part of the new research [28], the number of parks was analyzed in terms of the total area of parks in relation to the number of inhabitants in 50 large German cities. Post-industrial Gelsenkirchen is among the 10 greenest cities in Germany, with $16.85 \mathrm{~m}^{2}$ of green space per inhabitant. It is located in the North Rhine-Westphalia conurbation. Few people associate vast green spaces with the Ruhr-but this is a misconception because in Gelsenkirchen itself, in the middle of the district, parks cover a total area of $4.39 \mathrm{~km}^{2}$.

According to the new system, the fees set on the basis of the size of sealed surfaces from which the outflow is directed to the sewage network, the care for the natural retention of rainwater increases. Already at the design stage, paved areas (including roofs) are designated, and the method of rainwater drainage is specified. The amount of the fee is determined by multiplying the hardened areas with runoff coefficients. This solution is beneficial for multi-family housing, where the fee for the area is shared by all users (while in the previous legal solution it was proportional to water consumption by all residents). However, this tariff is unprofitable for large estates inhabited by a small number of people. Therefore, a solution was found in the form of payment for rainwater actually discharged into the sewage system. An additional task of introducing the system was to motivate payers to reduce the outflow from their plots. Investors willingly decide on alternative solutions, such as the use of rainwater infiltration devices, because they exempt from tax, while the traditional solution for draining all rainwater from the plot surface to the sewage network) is associated with the payment of a fee. Another way to obtain partial tax exemption is to use retention elements. Then, $15 \mathrm{~m}^{2}$ is deducted from the obtained area (in each group of the runoff coefficient) for each $1 \mathrm{~m}^{3}$ of the installed reservoir [29]. The legal solution supports environmental activities.

The densely populated industrial city of Gelsenkirchen has around a quarter of its green areas under landscape or nature protection [30]. Among the open areas, the most popular is the Nordsternpark, which was built on the site of a former mine and combines the historical remains of industrial facilities with a modern park landscape (Figure 10). The next place is Consol Park, which is also located on the site of an old mine and, thanks to its considerable tree cover, is a green island enabling the revival of biodiversity in postindustrial areas. One of the oldest green areas in the region is Nienhausenbusch with a leisure and sports tradition for the city. Four times a week on the racetrack (Trabrenn-bahn Gelsenkirchen), apart from horse racing, there are also so-called a flea market that activates the local community. The total area of the parks in Gelsenkirchen is $4.39 \mathrm{~km}^{2}$. 


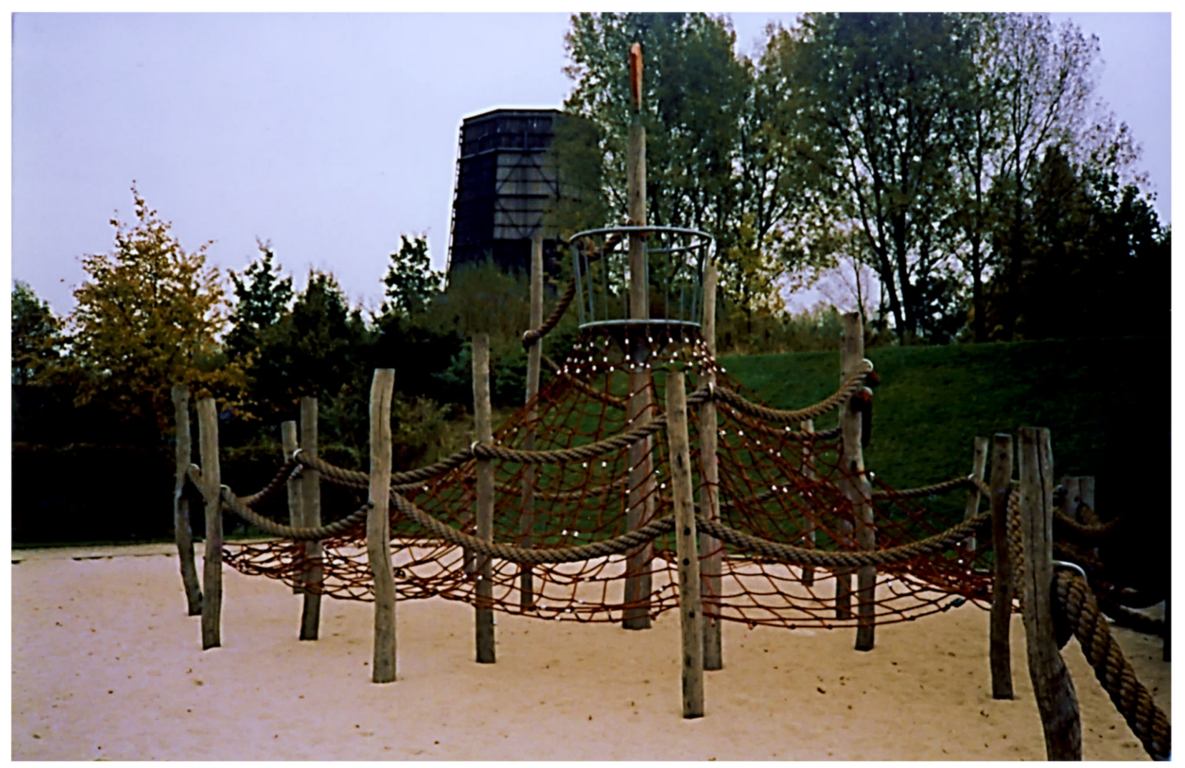

Figure 10. Green areas, relaxation areas against the background of the still old wooden cooling tower in Nordsternpark Gelsenkirchen. Source: photo by the author.

Gelsenkirchen also has another important element of green infrastructure, i.e., insulating forest greenery for the Rheinelbe mining industry (since 1996 it has been treated as a forest park). The Rheinelbe Gelsenkirchen forest park is part of the "Industrial Forest Ruhr Area" project, whose origins date back to the International Exhibition Budowlana (IBA) Emscher Park (1989-1999)—then still under the name of the "Residual Area Project". At the time of IBA [31], due to the structural changes in the Ruhr area, there was a great need to develop a concept for the re-use of 10,000 hectares of abandoned industrial land with little availability of financial resources [32]. The urban forest project aims, inter alia, to increase the share of forests in inner-city areas, while enabling natural processes of succession, bioretention and the availability of recreational areas. The project covers 13 sub-areas with a total area of approximately 205 hectares (Figure 11) and has been implemented since 2002. He is looked after by the Landesbetrieb Wald und Holz NRW. The location of the former Rheinelbe mine as one of these project areas covers 36 hectares, and the park area includes a post-mining heap, which due to its specificity [33] is also considered one of the monuments on the post-industrial culture route of the region.

As a result of the project to complete the isolation forest area around Reinelbe, inaccessible undeveloped land has been transformed into useful open spaces that retained as much bioretention as possible. An innovative feature of this experimental project was the concept of "urban wilderness" (Figure 12), whereby areas could develop freely through succession and bioretention. When necessary, human interventions are carried out in accordance with the principle of fostering development, for example to ensure the safety of visitors or to promote biodiversity (Table 8). For this, there is a deliberately simple maintenance plan and annual work programs.

In many practical examples, increasing the accessibility and accessibility of urban green spaces (near the house) is accomplished by opening and creating new path systems. Harnessing the potential for unsealing, increasing the greening of paths and streets to reduce heat loads and bind air pollutants can also be found in many places. In addition, an additional aim is to filter pollutants and bind fine dust, as well as to reduce noise pollution (integrating the spatial development plan and linking the city of Mülheim an der Ruhr by means of urban greenery with recreational functions. 


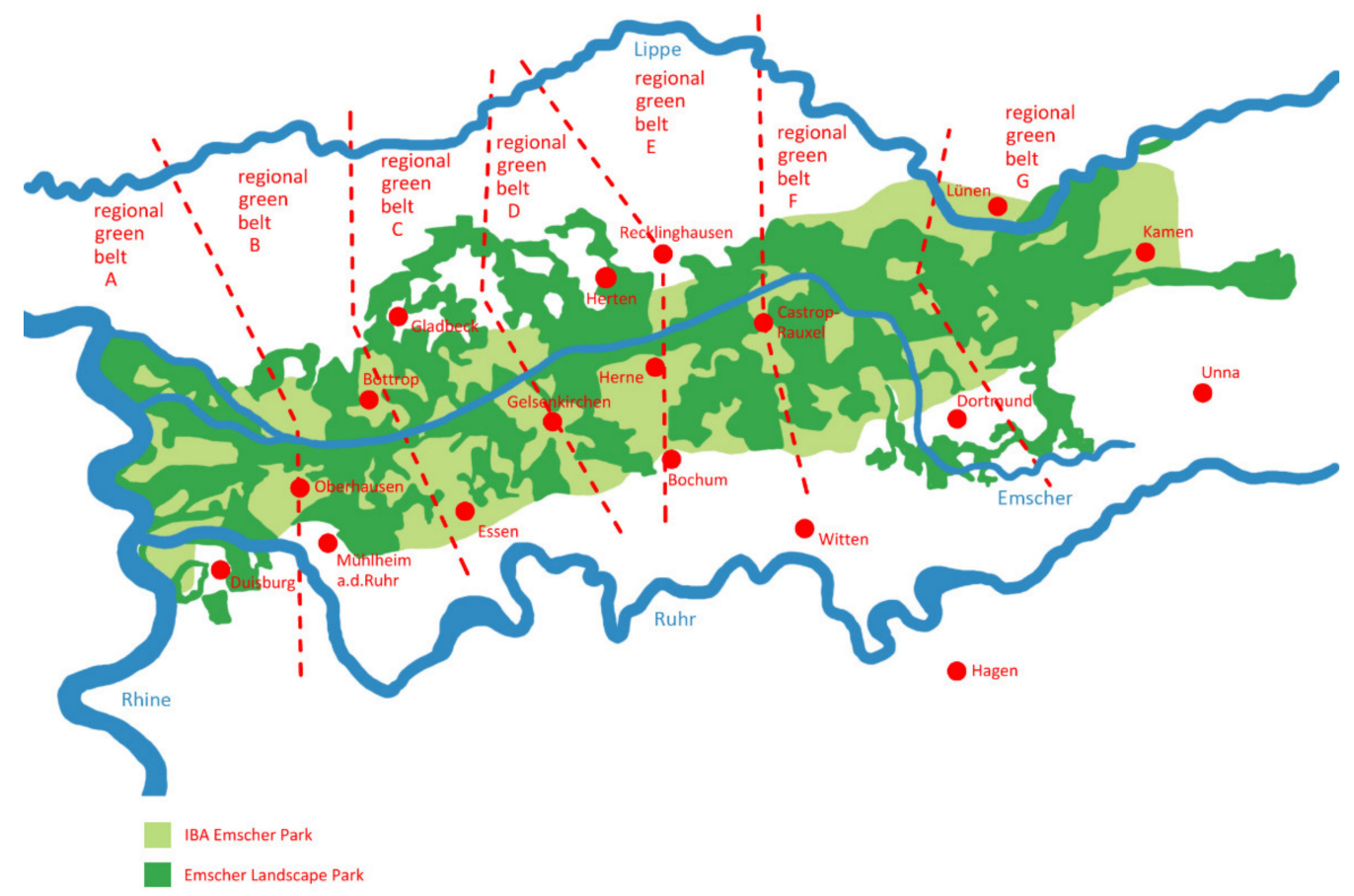

Figure 11. Summary of green areas along the Emscher River in the Ruhr area. Source: link.springer.com/book/10.1007/97 8-4-431-56445-4 (accessed on 22 July 2021).

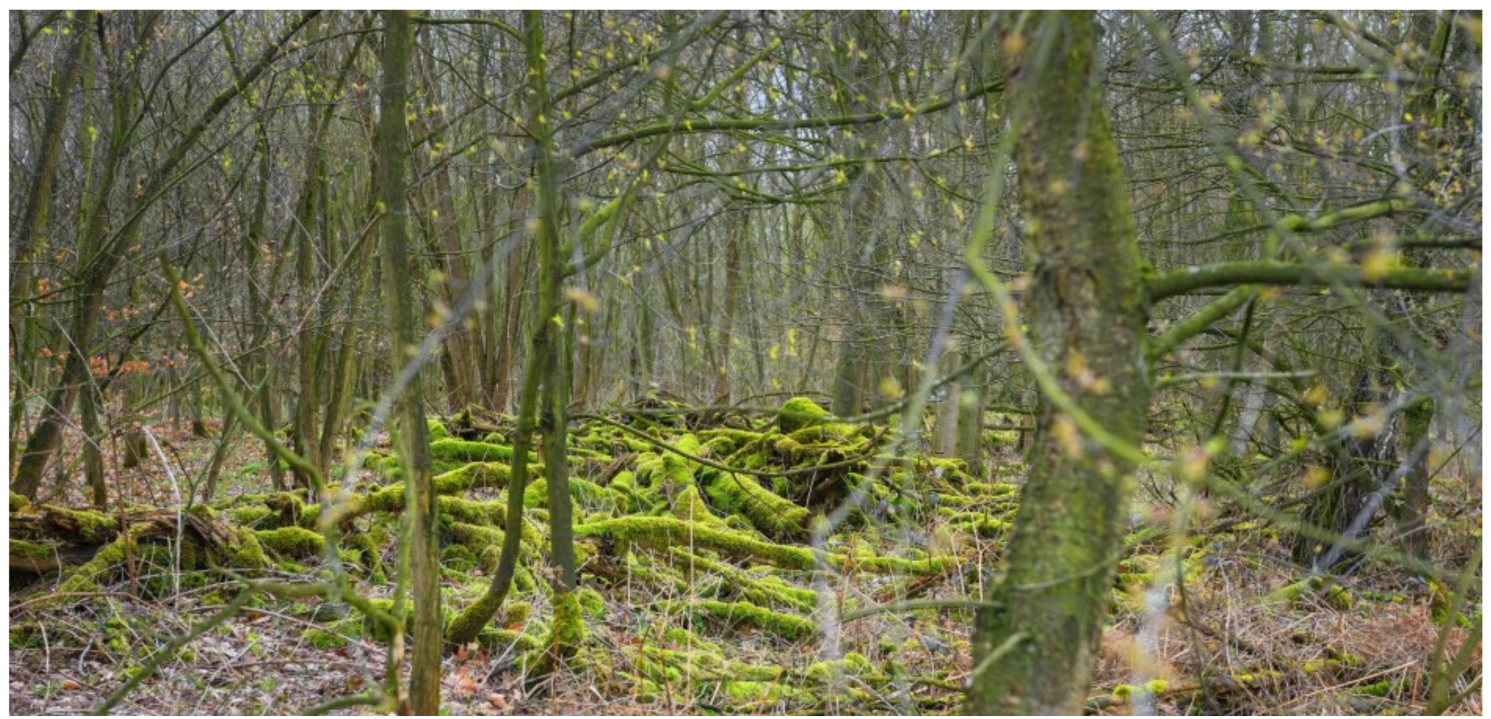

Figure 12. Urban wilderness in the post-industrial Rheinelbe forest complemented by design elements (S. Pauleit). Funding for design and environmental activities was provided through IBA Emscher Park. Source: www.waz.de/staedte/gelsenkirchen/ auf-jeden-gelsenkirchener-buerger-kommen-33-quadratmeter-wald-id216746705.html (accessed on 23 May 2021). 
Table 8. Development strategy based on the example of selected cities. Source: www.bfn.de/fileadmin/BfN/service/

Dokumente/skripten/Skript503.pdf (accessed on 23 May 2021).

\begin{tabular}{|c|c|c|c|c|c|}
\hline \multirow[b]{2}{*}{ City } & \multirow[b]{2}{*}{ Project } & \multicolumn{4}{|c|}{ Strategic Objectives ${ }^{1}$} \\
\hline & & $\begin{array}{l}\text { Health and } \\
\text { Quality of } \\
\text { Life }\end{array}$ & $\begin{array}{l}\text { Adaptation to } \\
\text { Climate } \\
\text { Changes }\end{array}$ & $\begin{array}{l}\text { Biodiversity } \\
\text { and Nature } \\
\text { Experience }\end{array}$ & $\begin{array}{l}\text { Influence on } \\
\text { Community } \\
\text { Activation }\end{array}$ \\
\hline Berlin & $\begin{array}{l}\text { Landschaftsprogramm-Landscape } \\
\text { protection plan }\end{array}$ & $x x$ & $x x$ & $x x$ & $\mathrm{x}$ \\
\hline Bremen & $\begin{array}{c}\text { Landschaftsprogramm und } \\
\text { Flächennutzungsplan-Landscape } \\
\text { protection plan and spatial development } \\
\text { plan }\end{array}$ & $x x$ & $\mathrm{xx}$ & $x x$ & $\mathrm{x}$ \\
\hline Norderstedt & Landschaftsplan-Landscape plan & $x x$ & $x$ & $\mathrm{x}$ & $\mathrm{x}$ \\
\hline Frankfurt/a M. & $\begin{array}{l}\text { Leitbild für den Grüngürtel und } \\
\text { Gesamtstädtliche Grundstrategie-Green } \\
\text { Belt Mission and Overall City Strategy }\end{array}$ & $x x$ & $\mathrm{xx}$ & $\mathrm{x}$ & $x x$ \\
\hline Kiel & $\begin{array}{c}\text { Freiraumliches Leitbild und integriertes } \\
\text { Stadtentwicklungskonzept-Open space } \\
\text { model and integrated concept of urban } \\
\text { development }\end{array}$ & $x x$ & $\mathrm{xx}$ & $x x$ & $x x$ \\
\hline Saarbrücken & $\begin{array}{c}\text { Freiraumentwicklung Programm und } \\
\text { städtische Freiraumplanung[ ... ] für } \\
\text { adaptionsmaßnahmen-The development } \\
\text { of open spaces and urban planning for } \\
\text { adaptation activities }\end{array}$ & $x x$ & $\mathrm{xx}$ & $\mathrm{x}$ & $\mathrm{x}$ \\
\hline Erfurt & $\begin{array}{l}\text { Umsetzungsplan Biologische } \\
\text { Vielfalt-Biodiversity Implementation Plan }\end{array}$ & - & - & $x x x$ & $\mathrm{x}$ \\
\hline Essen $^{2}$ & $\begin{array}{l}\text { Stadtentwicklungsprozess 2015+-2015+ } \\
\text { city development }\end{array}$ & $\mathrm{xx}$ & - & - & $\mathrm{x}$ \\
\hline Hamburg & Gründachstrategie-Green Roof Strategy & $\mathrm{xx}$ & $x x x$ & $\mathrm{x}$ & $\mathrm{x}$ \\
\hline Münster & $\begin{array}{l}\text { Klimaanspassungskonzept und } \\
\text { Aasee-Leitbild-Climate adaptation } \\
\text { concept and Aasee's vision }\end{array}$ & $x x$ & $x x x$ & $\mathrm{x}$ & $x x$ \\
\hline München & Isar-Plan-Plan for the Isar River & $x x$ & $x x x$ & $x x x$ & $\mathrm{x}$ \\
\hline Mülheim ${ }^{2}$ & $\begin{array}{l}\text { Masterplan Spielen und } \\
\text { Beweegen-General plan for outdoor } \\
\text { activities and games }\end{array}$ & $\mathrm{xxx}$ & $\mathrm{x}$ & $\mathrm{x}$ & $x x x$ \\
\hline Gelsenkirchen $^{2}$ & $\begin{array}{l}\text { Industriewald Rheinelbe-Rheinelbe } \\
\text { post-industrial forest }\end{array}$ & $x x$ & - & $x x$ & $\mathrm{x}$ \\
\hline Krefeld $^{2}$ & $\begin{array}{l}\text { Rheindeich von Krefeld-Uerdingen-Dike } \\
\text { on the river Rhine Krefeld-uerdingen }\end{array}$ & $x x$ & $x x x$ & - & $\mathrm{x}$ \\
\hline
\end{tabular}

\subsubsection{Ecomuseum Bergslagen}

The Ekomuseum Bergslagen (Figure 13) can also inspire the direction of transformations in post-industrial areas. The assumption, in line with the spirit accompanying the rehabilitation measures in Sweden, is shaped in the natural landscape, enabling natural water filtration and bioreference. The urban layout is based on the history of iron and coal mining and the tradition of metallurgy. The Ekomuseum Bergslagen consists of around 60 sightseeing places that are related to iron processing and the technological process from coal production and mines to ironworks in the north of the entire establishment. The 
Ecomuseum as a concept was established in 1971 by the International Council of Museums in Grenoble.

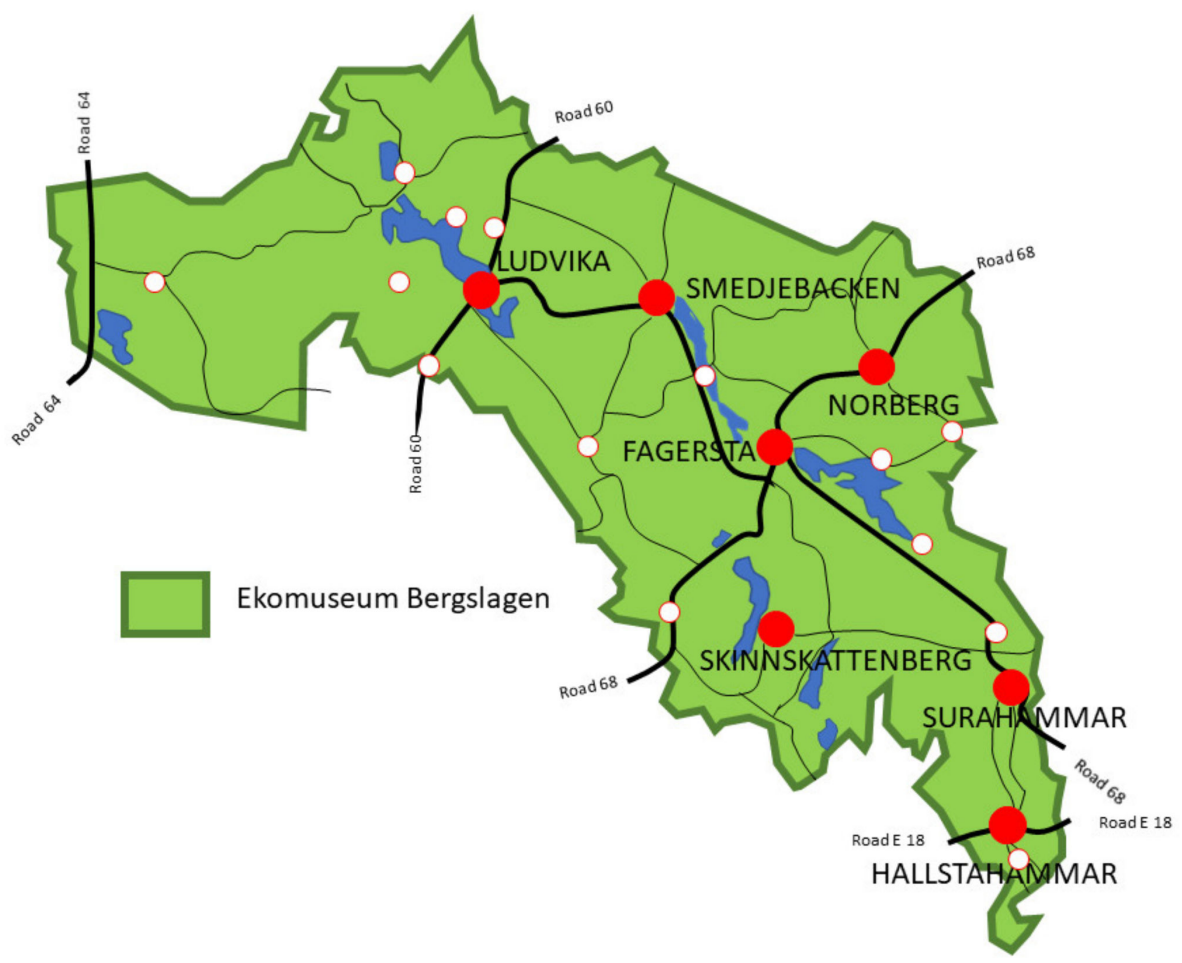

Figure 13. Ecomuseum Bergslagern [34].

In areas with cold climates, the management of rainwater with biorentent systems in winter encounters some difficulties, such as limited biological activity, temporary freezing and sometimes the salinity of roads. Studies on the efficiency of bioretention systems and treatment capacity in cold climates have shown that bioretention systems perform well even in cold conditions. Studies carried out in central Sweden have shown that [35] when selecting plants for a biorentency system, attention should be paid to plants that tolerate dry to normal ground conditions. Sweden's climate situation is somewhat different, but its experiences for our climate, which is not as mild as in Germany, are interesting in relation to Poland. Research on Sweden [36] shows that even in a cold climate and in a cold period, positive effects of bioretention can be counted.

The central area of Sweden is the cradle of metallurgy and the leitmotif for the park system is "iron history" with a focus on technology, human living conditions, transport routes and available natural resources. The area stretches from Grangärde Finnmark in the north, where woodland areas produced charcoal for the smithy, all the way to Lake Mälaren and Borgåsund Harbor in the south, where ironware was transhipped for further transport. The processing of iron (but also copper and silver) by Bergslagens was of great economic importance for Sweden [37]. As in IBA Emsher Park, the common thread connecting the whole area is the navigable and transport channel Strömsholm. Places to visit include the Lokmuseet (railway museum) in Grängesberg, the medieval Bergslagen museum, the Lapphyttan which is one of the oldest known blast furnaces in Europe, the owners' castle in Strömsholm. The area covers approximately $750 \mathrm{~km}^{2}$ of exhibition space (Figure 14). 

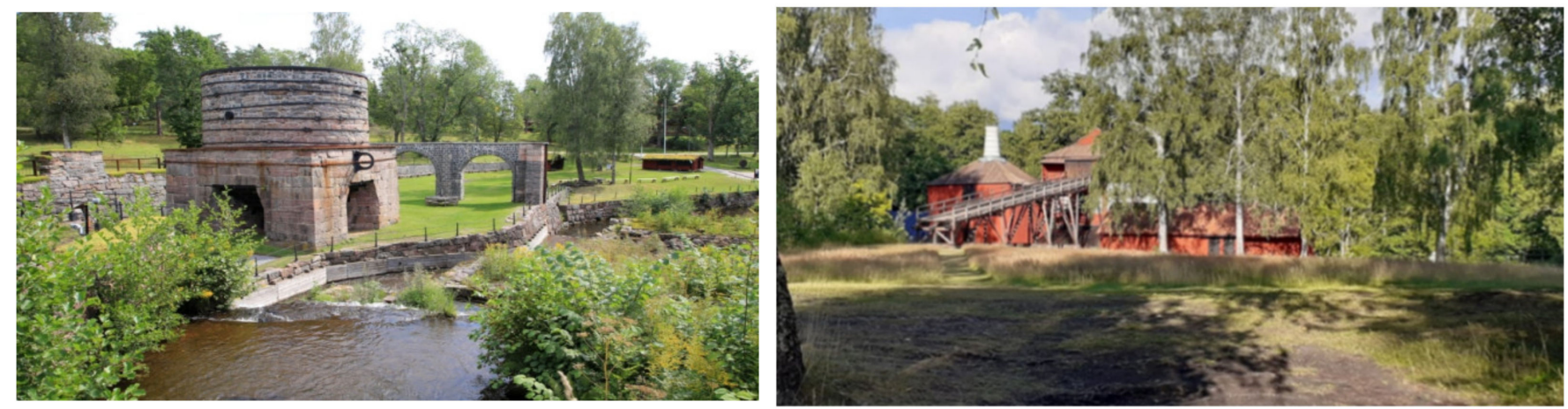

Figure 14. Stopping places in the eco-park with the remains of industrial structures blended in and complementing the landscape. On the left, the Borgviks blast furnace-built in 1863-1865 is part of a post-industrial park using the natural environment [38]. On the right-in place of the original furnace, a new blast furnace was built in 1882, which has survived to this day with a water turbine, boiler, steam engine and cylinder blower. 2008-own resources.

\section{Conclusions}

Post-industrial areas are one of the few sites that can be reclaimed to improve bioretention in large agglomerations. In Central Europe, they are successively released by the industry withdrawing from the market and quickly redeveloped for non-environmental purposes. Cracow is an example of a city with significant changes in its structure. Much land has already been lost to the natural environment due to new residential functions. Of the larger areas that can be developed according to the bioretention principle, 3 large areas remain, each of which is larger than the historic city center. Two of them are initially considered for urbanized service, housing and accompanying functions, the third has not yet been received in the planning guidelines and has not been published in the direction of transforming the Development Strategy of the City of Cracow [39]. As the calculations show, it is an area with high bio-retention potential, as well as environmental, climatic and cultural potential for hybrids. The benefits of creating hydrological windows are not sufficiently appreciated by the authors of spatial development plans. Important information for city authorities should also be the information that post-industrial areas do not need to be razed to the ground-Swedish and German examples show it. They can also be parks with a landscape or even quasi-natural character. Whether office buildings and blocks of flats or old factories are visually more attractive is a matter of individual assessment. However, industry was part of the history of Cracow, providing employment to the population of Cracow and the surrounding area. It was an element firmly rooted in the city's tradition and economically more reliable than business centers that could be relocated very quickly. Most of the areas after the liquidation of industry in Cracow were taken over for service and housing functions. Only the quarries, as difficult to use, managed to defend themselves and were transformed by plant succession into green areas. Political, economic and environmental changes meant that the next two large post-industrial areas will also have service and housing functions. The last possible area to be transformed into an area with natural functions is the area of the Acelormittal smelter-which closed production and considers various possibilities of "getting rid of out "of the terrain. Due to the "concreting of the city", it is the only possibility of maintaining a larger area of land of cultural, climatic and environmental importance. Post-industrial areas are a huge potential for bioretention, which is a way to purify rainwater from pollutants, and a chance to improve the microclimate, and increase the level of air humidity by up to $40 \%$, which helps to alleviate heat, prevent allergies and allow residents to improve the quality of life for residents. 
Author Contributions: Conceptualization, R.B., H.H.-G.; methodology R.B., H.H.-G.; validation, R.B., H.H.-G.; data analysis, H.H.-G., A.H.-N.; writing-original draft preparation R.B., H.H.-G., A.H.-N.; writing—review and editing, R.B., A.H.-N., visualization, H.H.-G., A.H.-N.; supervision, R.B. All authors have read and agreed to the published version of the manuscript.

Funding: This research received no external funding.

Conflicts of Interest: The authors declare no conflict of interest.

\section{References}

1. Meilvang, M.L. From Rain as Risk to Rain as Resource: Professional and Organizational Changes in Urban Rainwater Management. Curr. Sociol. 2021. [CrossRef]

2. Paddison, R. Handbook of Urban Studies; SAGE Publications Ltd.: Thousand Oaks, CA, USA, 1998; ISBN 978-1-84787-663-8.

3. Tahvonen, O. Adapting Bioretention Construction Details to Local Practices in Finland. Sustainability 2018, 10, 276. [CrossRef]

4. Ćopić, S.; Đorđevića, J.; Lukić, T.; Stojanović, V.; Đukičin, S.; Besermenji, S.; Stamenković, I.; Tumarić, A. Transformation of Industrial Heritage: An Example of Tourism Industry Development in the Ruhr Area (Germany). Geogr. Pannonica 2014, 18, 43-50. [CrossRef]

5. Wolski, P. The Importance of Hydrological Windows. Szkoła Główna Gospodarstwa Wiejskiego, Wydział Ogrodnictwa. Biotechnol. i Archit. Kraj. 2013, 26, 129-144.

6. Life UrbanGreen. Pilot Areas. Available online: https://www.lifeurbangreen.eu/pilot-areas/ (accessed on 23 May 2021).

7. Łaszkiewicz, E.; Kronenberg, J.; Marcińczak, S. Attached to or Bound to a Place? The Impact of Green Space Availability on Residential Duration: The Environmental Justice Perspective. Ecosyst. Serv. 2018, 30, 309-317. [CrossRef]

8. Minister of Infrastructure. Rozporządzenie Ministra Infrastruktury z Dnia 12 Kwietnia 2002 r. w Sprawie Warunków Technicznych, Jakim Powinny Odpowiadać Budynki i Ich Usytuowanie. Ordinance of the Minister of Infrastructure of April 12, 2002 on Technical Conditions to Be Met by Buildings and Their Location. Available online: https://isap.sejm.gov.pl/isap.nsf/ DocDetails.xsp?id=WDU20020750690 (accessed on 30 May 2021).

9. Ecomuseum Bergslagen. Available online: https://visitworldheritage.com/en/eu/ecomuseum-bergslagen/0ac54643-407c-4e418ce0-5c466487ae93 (accessed on 23 May 2021).

10. Stanilov, K.; Sýkora, L. Confronting Suburbanization: Urban Decentralization in Postsocialist Central and Eastern Europe; John Wiley \& Sons: Hoboken, NJ, USA, 2014; ISBN 978-1-4051-8548-6.

11. Available online: https://www.klimat.geo.uj.edu.pl/tematyczne/klimatkrakowa/opady.htm (accessed on 22 July 2021).

12. Stanilov, K. The Post-Socialist City: Urban Form and Space Transformations in Central and Eastern Europe after Socialism; Springer Science \& Business Media B.V.: Dordrecht, The Netherlands, 2007; ISBN 978-1-4020-6053-3.

13. Communication From the Commission to the European Parliament, the Council, the European Economic and Social Committee and the Committee of the Regions Green Infrastructure (GI)_Enhancing Europe's Natural Capital 2013. Available online: https:/ / eur-lex.europa.eu/legal-content/PL/TXT/PDF/?uri=CELEX:52013DC0249\&from=PL (accessed on 23 May 2021).

14. Available online: http://krakow.rdos.gov.pl/informacja-w-sprawie-wyznaczenia-strefy-ochrony-gniewosza-plamistego-nazakrzowku-w-krakowie (accessed on 23 May 2021).

15. Górecki, J.; Sermet, E. Kamieniołomy Krakowa-Dziedzictwo niedocenione. Krakow Quarries—Underestimated Heritage 2021. Available online: http:/ / history-of-mining.pwr.wroc.pl/old/attachments/article/22/12GoreckiSermet-Kamienio\%C5\%82omy_ Krakowa.pdf (accessed on 23 May 2021).

16. Jucu, I.S.; Voiculescu, S. Abandoned Places and Urban Marginalized Sites in Lugoj Municipality, Three Decades after Romania's State-Socialist Collapse. Sustainability 2020, 12, 7627. [CrossRef]

17. Ioan Sebastian, J. From State-Socialist Ambitions of Romanian Rural Indutrialisation to Post-Socialist Rural Deindutrialisation: Two Case Studies from Romania. East. Eur. Countrys. 2016, 22, 165-195. [CrossRef]

18. Caraco, D.; Claytor, R. Stormwater BMP Design Supplement for Cold Climates 1997. Available online: https:/ / owl.cwp.org/ mdocs-posts / caracod-_sw_bmp_design_cold_climates/(accessed on 23 May 2021).

19. Available online: https://www.krakow.pl/zalacznik/382386/4 (accessed on 23 May 2021).

20. Available online: https://niaiu.pl/wp-content/uploads (accessed on 23 May 2021).

21. Available online: https://www.bip.Cracow.pl/?dok_id=116458 (accessed on 23 May 2021).

22. Available online: https://lovekrakow.pl/aktualnosci/w-krakowie-powstanie-nowe-miasto-z-17-wysokosciowcami-ponad100-tys-mieszkancow_41066.html (accessed on 23 May 2021).

23. Available online: https://umk-gd.maps.arcgis.com/apps/MapSeries/index.html?appid=81480b0233ab4163a376936410be9064 (accessed on 23 May 2021).

24. Kelleher, C.; Golden, H.E.; Burkholder, S.; Shuster, W. Urban Vacant Lands Impart Hydrological Benefits across City Landscapes. Nat. Commun. 2020, 11, 1563. [CrossRef]

25. Elliott, R.M.; Adkins, E.R.; Culligan, P.J.; Palmer, M.I. Stormwater Infiltration Capacity of Street Tree Pits: Quantifying the Influence of Different Design and Management Strategies in New York City. Ecological Engineering 2018, 111, 157-166. [CrossRef]

26. Nguyen, T.T.; Ngo, H.H.; Guo, W.; Wang, X.C.; Ren, N.; Li, G.; Ding, J.; Liang, H. Implementation of a Specific Urban WaterManagement-Sponge City. Sci. Total. Environ. 2019, 652, 147-162. [CrossRef] [PubMed] 
27. Richter, B.; Grunewald, K.; Meinel, G. Analyse von Wegedistanzen in Städten zur Verifizierung des Ökosystemleistungsindikators „Erreichbarkeit städtischer Grünflächen; Wichmann VerlagGmbH: Berlin, Germany, 2016; ISBN 978-3-87907-622-2.

28. Wojciechowska, E.; Gajewska, M.; Matej-Łukowicz, K. Wybrane aspekty zrównoważonego gospodarowania wodami opadowymi na terenie zurbanizowanym. Selected Aspects of Sustainable Rainwater Management in an Urbanized Area. 78. Available online: http:/ / www.geomatyka.eu/publikacje/isbn9788360261514/isbn9788360261514.pdf (accessed on 23 May 2021).

29. Sures, B.; Dangel, D.; Eisinger, M.; Dettmar, J. Nature and the Quality of Life: The Ruhr Metropolitan Region as a Sustainable Urban Cultural Landscape (KuLaRuhr). Kohlhammer-Natur-und-Landschaft 2015, 90, 354-359. [CrossRef]

30. Kilper, H. Die Internationale Bauausstellung Emscher Park: Eine Studie zur Steuerungsproblematik Komplexer Erneuerungsprozesse in Einer Alten Industrieregion; Springer Science+Business Media B.V.: Dordrecht, The Netherlands, 2013; ISBN 978-3-663-09727-3.

31. Bostenaru Dan, M.; Bostenaru-Dan, M.M. Greening the Brownfields of Thermal Power Plants in Rural Areas, an Example from Romania, Set in the Context of Developments in the Industrialized Country of Germany. Sustainability 2021, 13, 3800. [CrossRef]

32. Ciesielczuk, J.; Janeczek, J.; Cebulak, S. Przebieg i przyczyny endogenicznego pożaru węgla kamiennego na zrekultywowanym składowisku odpadów komunalnych w Katowicach. The course and causes of endogenous hard coal fire in the reclaimed municipal waste landfill in Katowice. Przeglad Geol. 2013, 61, 10. Available online: https://www.pgi.gov.pl/dokumentyprzegladarka/publikacje-2/przeglad-geologiczny/2013/grudzien-1/2047-przebieg-i-przyczyny/file.html (accessed on 23 May 2021).

33. Bergdhal, E. Ecomuseo Bergslagen, Un Proyecto Sueco de Parque Cultural. Identidades: Territorio, Cultura, Patrimonio; Laboratorio Internacional de Paisajes Culturales: Cataluna, Portugal, 2005. [CrossRef]

34. Malin Hiller Funktion Och Vegetation För Biofilter i Kallt Klimat: Med Fokus På Gävle. 2016. Available online: http:/ /hig.divaportal.org/smash/get/diva2:1057064/FULLTEXT01.pdf (accessed on 23 May 2021).

35. Yachnin, O. System för Lokalt Omhändertagande av Dagvatten. Available online: https://stud.epsilon.slu.se/13685/ (accessed on 30 May 2021).

36. Hrehorowicz-Nowak, H. Relikty Historycznych Założeń Przemysłowych Jako Element Atrakcyjności Turystycznej. Sprawozdania z Posiedzeń Komisji Naukowych 2004. Relics of Historical Industrial Assumptions as an Element of Tourist Attractiveness. Reports from the 2004 Scientific Committee Meetings; Cracow University of Technology: Cracow, Poland, 2004; pp. 161-162.

37. Available online: https://svefin.wordpress.com/2021/02/03/industrial-heritage-borgviks-blast-furnace/ (accessed on 22 May 2021).

38. Municipality of Cracow Municipality of Cracow City Development. This Is Where I Want to Live. Cracow 2O3O. Cracow Development Strategy 2018. Available online: https: / www.bip.krakow.pl/plik.php?zid=225388\&wer=0\&new=t\&mode=shw (accessed on 23 May 2021).

39. Gyurkovich, M.; Gyurkovich, J. New Housing Complexes in Post-Industrial Areas in City Centres in Poland Versus Cultural and Natural Heritage Protection-With a Particular Focus on Cracow. Sustainability 2021, 13, 418. [CrossRef] 